\title{
Performance Comparison between Structural Element of Building Systems in Malaysia
}

\author{
${ }^{1}$ M.R. Abdul Kadir, ${ }^{2}$ W.P. Lee, ${ }^{2}$ M.S. Jaafar, ${ }^{3}$ S.M. Sapuan and ${ }^{1}$ A.A.A. Ali \\ ${ }^{1}$ Housing Research Centre, ${ }^{2}$ Department of Civil Engineering \\ ${ }^{3}$ Department of Mechanical and Manufacturing Engineering, Faculty of Engineering \\ Universiti Putra Malaysia, 43400 UPM Serdang, Malaysia
}

\begin{abstract}
The Industrialized Building System (IBS) was introduced in Malaysia in 1966, but it failed to establish itself on a continuous basis though there has been a sustained large market for residential projects even since. One of the reasons behind this shortcoming is the lack of scientific data on labor productivity that could convince policy maker. Hence, the objective of this study is to develop a standardized data collection methodology for measuring and comparing the conventional building system and IBS in term of labor productivity, crew size and cycle time. Labor productivity (man hours $/ \mathrm{m}^{2}$ ) is defined as the man hours required to complete the structural element of one unit house. A total of 499 data points were obtained from seven residential projects constructed between January 2003 and April 2004. Analysis of Variance (ANOVA) indicated that the labor productivity was significantly different between four structural building systems. The mean labor productivity for the conventional building system was 4.20 man hours $/ \mathrm{m}^{2}$ followed by cast in-situ table form (2.70 man hours $\left./ \mathrm{m}^{2}\right)$, cast in-situ half tunnel form $\left(1.88 \mathrm{man}\right.$ hours $\left./ \mathrm{m}^{2}\right)$ and pre-cast concrete system (1.33 man hours $/ \mathrm{m}^{2}$ ). Further, the analysis of crew size indicated that the mean crew size of a conventional building system of 24 workers was significantly different from the IBS of 22 workers. However, the crew size within the IBS was found to be insignificant. The cycle time measured in days per house was found to be significantly different between structural building systems with the conventional building system of 4.9 days, cast in-situ table form of 3.9 days, cast $i n$-situ half tunnel form of 2.9 days and precast concrete system for 2.3 days. The labor productivity obtained from this study could be used as a preliminary guideline for a client or consultant to identify the most appropriate building system for executing a construction project and determining the labor requirement in the construction industry.
\end{abstract}

Key words: Labor Productivity, Crew Size, Cycle Time, Industrialized Building System, Residential Project

\section{INTRODUCTION}

Construction labor productivity represents one of the core elements in the construction industry. Its paramount applications include construction planning, scheduling, cost estimating, accounting and cost control. Indeed, ${ }^{[1]}$ labor productivity rates are used to generate international labor factors and also suggested ways in which they could subsequently be applied to determine comparative international construction cost and labor required.

Many researchers have conducted the study on labor productivity for the construction industry. Nevertheless, the majority of them concentrated on labor intensive conventional construction system. Little attention is devoted to perplexing question such as productivity measurement for industrialized building systems (IBS) despite the proliferation of the systems in Malaysia. The growth of these IBSs is attributed to the need for huge demand for housing industry during the
Eighth Malaysia Plan (2001-2005) whereby 600,000 to 800,000 houses are expected to be built.

The conventional construction system which is presently being used by the construction industry is unable to cope with the demand in a stipulated period. The method is labor intensive and rely heavily on foreign workers. Thus, productivity research attention shall be devised toward IBS which employs the philosophy of assembly activity. There is an immense potential for productivity improvement in the building industry from craft activity to assembly activity as depicted in Table $1^{[2]}$.

Malaysia's Experience in IBS: The idea of using an industrialized building system in Malaysia was first mooted during the early sixties when the Minister of Housing and Local Government visited several European countries and evaluated their building system performance. Then, in 1964, the government took a brave decision to try two pilot projects using IBS concept. 


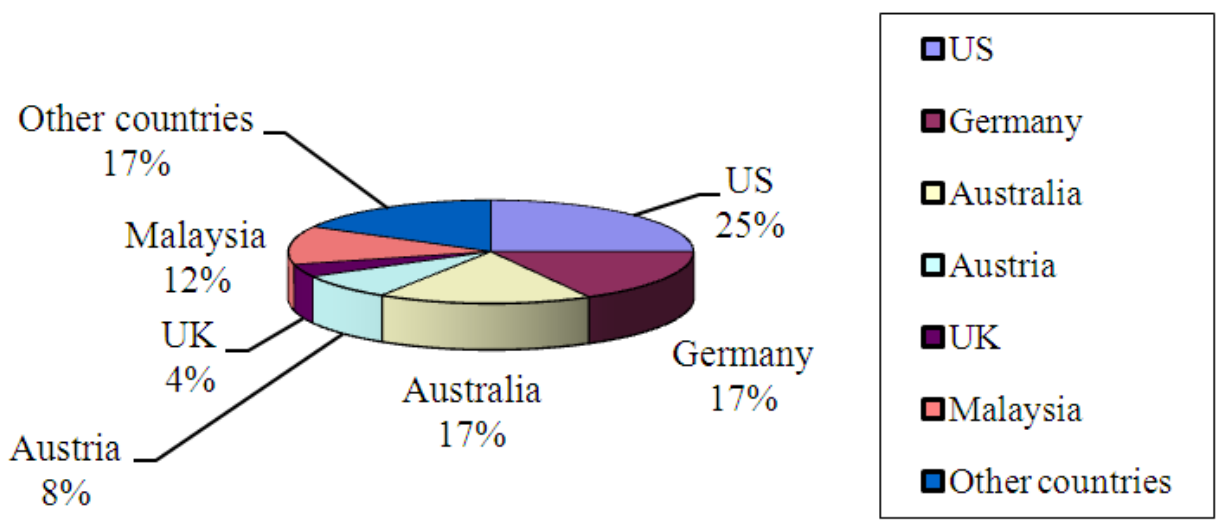

Fig. 1: Origin of IBS According to Countries ${ }^{[4]}$

Table 1: Usage of Workers and Potential for Productivity Improvement in Building Work ${ }^{[2]}$

\begin{tabular}{llllll}
\hline Work Type & $\begin{array}{l}\text { Usage of } \\
\text { Workers }(\%)\end{array}$ & $\begin{array}{l}\text { Usage of Foreign } \\
\text { Workers (\%) }\end{array}$ & $\begin{array}{l}\text { Potential for } \\
\text { Productivity } \\
\text { Improvement }\end{array}$ & Skills & Replaceable \\
\hline $\begin{array}{l}\text { Structural } \\
\text { Finishing }\end{array}$ & 50 & $80-85$ & High & $\begin{array}{l}\text { Craft } \\
\text { More craft } \\
\text { and less } \\
\text { assembly }\end{array}$ & $\begin{array}{l}\text { Assembly } \\
\text { Less craft } \\
\text { and more } \\
\text { assembly }\end{array}$ \\
Mechanical and Electrical & $15-35$ & $50-60$ & Medium & Assembly & Assembly \\
\hline
\end{tabular}

Table 2: Building System Classification According to Relative Weight of Component ${ }^{[10]}$

\begin{tabular}{lll}
\hline General System & System & Production Material \\
\hline Frame system & Light weight frame & Wood, light gage metals \\
& Medium light weight frame & Metal, reinforced plastics, laminated wood \\
Panel system & Heavy weight frame & Heavy steel, concrete \\
& Light and medium weight panel & Wood frame, metal frame and composite \\
& & materials \\
& Heavy weight panel (factory produced) & Concrete \\
& Heavy weight panel (tilt up -produced on site) & Concrete \\
Box system (modules) & Medium weight box (mobile) & Wood frame, light gage metal, composite \\
& Medium weight box (sectional) & Wood frame, light gage metal, composite \\
& Heavy weight box (factory produced) & Concrete \\
& Heavy box (tunnel produced on site) & Concrete \\
\hline
\end{tabular}

The first pilot project consisted of 7 blocks of 17 storey flats and 4 blocks of 4-storey flats comprising about 3,000 units of low cost flats and 40 storey shop lots. The project was awarded to the Gammon/Larsen Nielsen using the Danish System of large panel industrialized prefabricated systems. Meanwhile, the second pilot project was built in Pulau Pinang with the construction of 6 blocks of 17 storey flats and 3 blocks of 18 storey flats comprising 3,699 units and 66 shop lots along the Jalan Rifle Range. The project was awarded to Hochtief/Chee Seng using the French Estiot System $^{[3]}$.

With reference to the two pilot projects, a performance comparison between the IBS and conventional building system has been carried out in terms of cost, productivity and quality. It was discovered that the first pilot project incurred $8.1 \%$ higher cost than a similar building using conventional building system, while the second project was 2.6\% lower. In terms of construction speed, both projects required 27 months to complete, inclusive of time required to set up the precasting factories. The quality of building finishes was also found to be better than the conventional building system. In conclusion, the overall performance of an IBS is competitive with the conventional building system. Since then, the use of IBS has been more profound with the participation of private and public sectors such as Housing Research Centre in Universiti Putra Malaysia aimed at promoting and developing novel building system.

It was reported that at least 21 suppliers and manufacturers are actively involved in the dissemination of IBS in Malaysia ${ }^{[4]}$. The majority of the IBS originated from the United States, Germany and 
Australia with a market share of $25 \%, 17 \%$ and $17 \%$ respectively. Malaysian's produced systems only account for $12 \%$. Fig. 1 shows the source of IBS in Malaysia according the origin of countries.

Industrialized Building System: An Industrialized Building System (IBS) may be defined in which all building components such as wall, floor slab, beam, column and staircase are mass produced either in the factory or at site under strict quality control and minimal labor on site activities ${ }^{[5,}{ }^{6]}$. Esau and Nuruddin $^{[6]}$ asserted that an IBS is a continuum beginning from utilizing craftsmen for every aspect of construction to a system that make use of manufacturing production in order to minimize resource wastage and enhance value for end users.

Warszawski ${ }^{[8]}$ expounded that an industrialization process is an investment in equipment, facilities and technology with the objective of maximizing production output, minimizing labor resource and improving quality while a building system is defined as a set of interconnected element that join together to enable the designated performance of a building.

Perhaps the most comprehensive definition of IBS was given by Junid ${ }^{[8]}$. It was mentioned that an IBS in the construction industry includes the industrialized process whereby the components of a building are conceived, planned, fabricated, transported and erected on site. The system includes a balanced combination between the software and hardware components. The software elements include system design, which is a complex process of studying the requirement of the end user, market analysis, development of standardized components, establishment of manufacturing and assembly layout and process, allocation of resources and materials and the definition of a building designer conceptual framework. The software elements provide a prerequisite to create the conducive environment for an industrialized building system to expand.

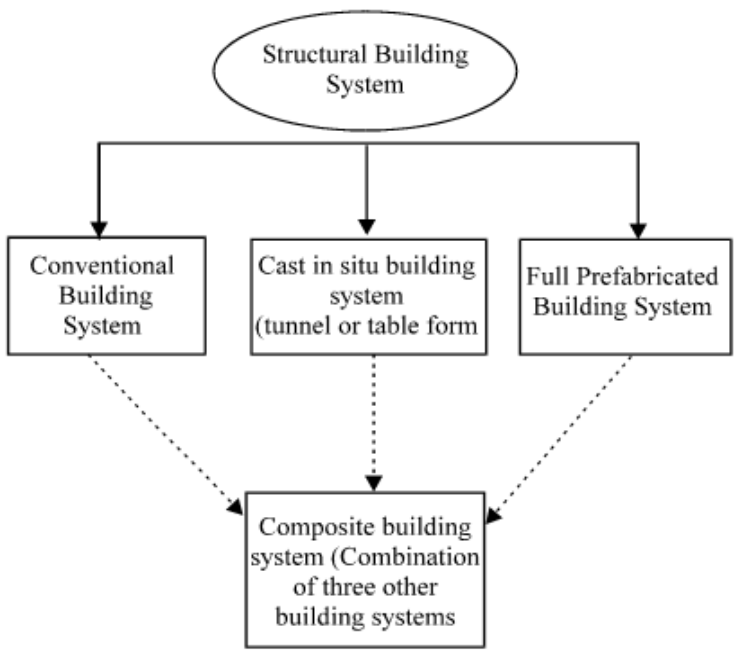

Fig. 2: Classification of Structural Building System ${ }^{[9]}$
The hardware elements are categorized into three major groups. These include frame or post and beam system, panel system and box system. The framed structure is defined as those structures that carries the loads through the beams and girders to columns and to the ground whilst in panel system, loads are distributed through large floor and wall panels. The box systems include those systems that employ three-dimensional modules (or boxes) for fabrication of habitable units that capable of withstanding load from various directions due to their internal stability.

\section{Classification of Industrialized Building System:} According to Badir-Razali building system classification $^{[10]}$, all building systems can be classified into four types of building system, namely conventional, cast in-situ, prefabricated and composite building systems as depicted in Fig. 2. The last three systems are identified as an Industrialized Building System (IBS). Each building system has peculiar characteristics in term of construction technology, erection sequence and labor requirement.

Warszawski $^{[7]}$ reported that the building systems could be classified in different ways, depending on the particular interest of their users or producers. Such classification uses construction technology as a basis for classifying different building systems. In this manner four major groups can be distinguished namely, system with timber, steel, cast in-situ concrete and precast concrete as their main structural and space enclosing materials. These systems can further be classified according to the geometrical configuration of their main framing components as linear or skeleton (beams and columns) system, planar or panel systems and three dimensional or box systems.

Majzub $^{[11]}$ expounded that the relative weight of components should be used as a basis for building classification as presented in Table 2. The factor of weight has significant impact on the transportability of the components and also has an influence on the production method of the components and their erection method on site. The classification by weight also has the advantage of distinguishing between the various basic materials used in the production of components which by itself could determine the characteristics of the system under study. However, the Majzub's classification method is found to be inadequate to be incorporated into other building systems that flourished recently. One of the distinct examples is the interlocking load bearing block which was the brainchild of a group of researchers in Universiti Putra Malaysia. This new building system cannot be categorized according to frame, panel or even box system. On the other hand, the composite system that combines two or more construction methods cannot also be categorized under the Majzub's classification. Hence, the classification needs to be updated to reflect the current technological advancement. 


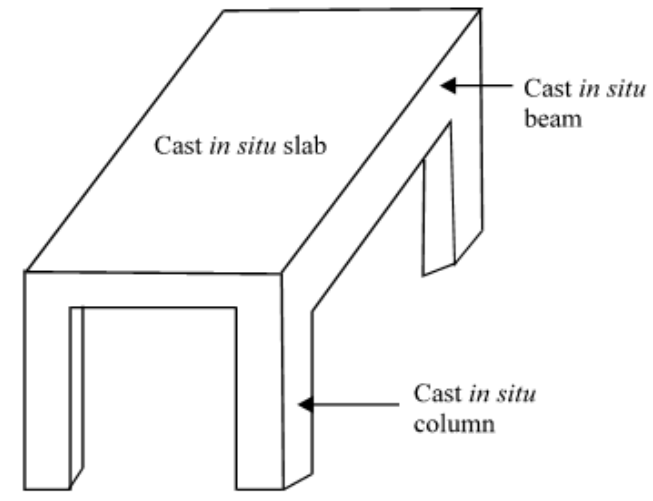

(a) Conventional Building System

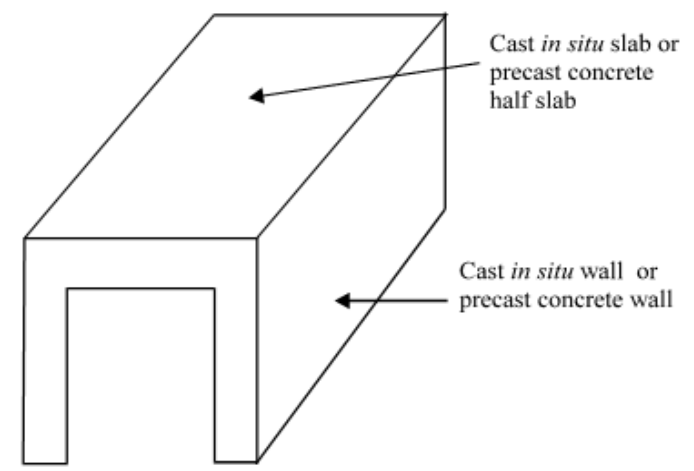

(b) Industrialised Building System

Fig. 3: Structural Element of One House

Objective: The classification of building systems expounded in the previous section will be used as a basis for the identification of residential projects for this study. Myriad of studies focused on labor productivity for single operation such concrete productivity ${ }^{[12]}$, rebar productivity ${ }^{[13]}$ and formwork productivity ${ }^{[14]}$. Little effort is devoted towards the combined labor productivity for all the single operation that join together to form the structural element of one unit house. Hence, this study presents a standardized data collection methodology for measuring and comparing the conventional and industrialized building systems in term of labor productivity, crew size and cycle time.

Description of Data: The data for this study were obtained from seven on-going residential projects constructed between January 2003 and April 2004. A total of 499 data points were observed during that period. The projects gross floor area per unit house range in size from $60 \mathrm{~m}^{2}$ to $84 \mathrm{~m}^{2}$. Four projects were built by turnkey contractors while the remaining project by a general contractor. The project characteristics are presented in Table 3.

Data Collection Methodology: A data point is defined as the completion of a structural element of one unit house which consists of all structural works such as column, beam and slab as illustrated in Fig. 3. These structural elements were installed and erected by carpenter, bartender, concrete and the crane operator. Thus, the labor productivity of one unit house is calculated below.

Labor productivity for structural element of one unit houses:

$=$ Crew Size (carpentry, bartender, concrete and crane operator) $\mathrm{x}$ work time

Building gross floor area $\left(\mathrm{m}^{2}\right)$

$=$ Total man hours

Building gross floor area, $\left(\mathrm{m}^{2}\right)$

All data were collected via a standardized data collection form as shown in Table 4. Data collectors were assigned to on-going construction sites on a daily basis and spent about 30 minutes per site to record the crew size, work time and location of the workplace. Daily observation is recommended because all workers were paid daily. Weekly or monthly observation is not suggested because workers absenteeism might occur during that period and data variability are too large to permit reliable analyses ${ }^{[15]}$. Daily observation can also show a high degree of variability due to various disturbance project related factors but not as much as other observations. Hourly observation is also not recommended because it is costly and time consuming. Confidential information such as workers' daily wage was obtained through direct interview with the project managers. Regular interviews to identify and understand any peculiarities delay and interruption to the projects were also carried out.

Rationale for Combining Data Points: The size of the data points has a direct impact on the appropriateness and reliability of statistical analysis. Small sample with 20 data points is suitable when a single independent.

A variable is used. However, a very sample of 1000 data points or more make the statistical analysis sensitive and unreliable ${ }^{[16]}$. Furthermore, erroneous data points resulting from peculiarities in observations or unusual conditions have a detrimental effect on the analysis.

The rationale for combining the data points from different projects into four structural building systems are as follows:

* All projects are residential projects. The structural designs are repetitive and do not have any peculiarities architectural features that requires special formwork system.

* All operations were carried out by semi-skilled and skill workers. The manual dexterity is about the same.

* All projects are located within $30 \mathrm{~km}$ distance, hence minimize the impact of weather and temperature. 
Table 3: Project Characteristics

\begin{tabular}{lllllll}
\hline $\begin{array}{l}\text { Project } \\
\text { Code }\end{array}$ & $\begin{array}{l}\text { Total Data } \\
\text { Point }\end{array}$ & $\begin{array}{l}\text { Structural } \\
\text { Building System } \\
\text { of Storey }\end{array}$ & $\begin{array}{l}\text { Number } \\
\text { Floor Area }\end{array}$ & $\begin{array}{l}\text { Gross } \\
\text { of crane }\end{array}$ & $\begin{array}{l}\text { Type } \\
\text { Contract }\end{array}$ & Type of \\
\hline A & 100 & $\begin{array}{l}\text { Conventional } \\
\text { column-beam-slab } \\
\text { frame system } \\
\text { Conventional } \\
\text { column-beam-slab } \\
\text { frame system }\end{array}$ & 12 & $71 \mathrm{~m}^{2}$ & Tower crane & Design and built \\
C & 66 & $84 \mathrm{~m}^{2}$ & Mobile crane & Conventional \\
D & 113 & $\begin{array}{l}\text { IBS Cast } \text { in-situ } \\
\text { table form }\end{array}$ & 8 & $60 \mathrm{~m}^{2}$ & Mobile crane & Design and built \\
E & 91 & $\begin{array}{l}\text { Cast } \text { in-situ } \\
\text { table form } \\
\text { Cast } \text { in-situ } \text { half } \\
\text { tunnel form }\end{array}$ & 20 & $76 \mathrm{~m}^{2}$ & Tower crane & Conventional \\
F & 45 & $\begin{array}{l}\text { Cast } \text { in-situ half } \\
\text { tunnel form } \\
\text { Pre-cast concrete } \\
\text { wall and half } \\
\text { pre-cast concrete } \\
\text { slab with concrete } \\
\text { topping (Pre-cast } \\
\text { concrete system) }\end{array}$ & 5 & $79 \mathrm{~m}^{2}$ & Tower crane & Conventional \\
& 48 & $60 \mathrm{~m}^{2}$ & Mobile crane & Design and built \\
& $70 \mathrm{~m}^{2}$ & Tower crane & Design and built \\
\hline
\end{tabular}

Table 4: Standardized Data Collection Form

\begin{tabular}{|c|c|c|c|c|}
\hline $\begin{array}{l}\text { Data Collection Form } \\
\text { Project code } \\
\text { Type of building system } \\
\text { for structural work }\end{array}$ & A & $\begin{array}{l}\text { Conventior } \\
\text { and plywor }\end{array}$ & $\begin{array}{l}\text { nn-beam-sla } \\
\text { mwork mate }\end{array}$ & system with timbe \\
\hline Level & 2 & Block & $\mathrm{B} 2$ & Number of Unit 6 \\
\hline No & Activity & Date & Crew Size & Work time \\
\hline 1 & Fabrication and & $26 / 1 / 03$ & 8 & 8 \\
\hline & $\begin{array}{l}\text { erection of column } \\
\text { reinforcement }\end{array}$ & $27 / 1 / 03$ & 8 & 8 \\
\hline 2 & Fabrication and & $29 / 1 / 03$ & 10 & 8 \\
\hline & $\begin{array}{l}\text { erection of column } \\
\text { formwork }\end{array}$ & $30 / 1 / 03$ & 8 & 8 \\
\hline 3 & Casting of column & $31 / 1 / 03$ & 8 & 8 \\
\hline 4 & Dismantling of & $4 / 2 / 2003$ & 3 & 8 \\
\hline & column formwork & $5 / 3 / 2003$ & 2 & 8 \\
\hline 5 & Fabrication and & $6 / 2 / 2003$ & 8 & 8 \\
\hline & erection of beam & $7 / 2 / 2003$ & 4 & 8 \\
\hline & and slab scaffolding & $8 / 2 / 2003$ & 5 & 8 \\
\hline & and formwork & $9 / 2 / 2003$ & 5 & 8 \\
\hline & & $10 / 2 / 2003$ & 6 & 8 \\
\hline 6 & Fabrication and erection & $11 / 2 / 2003$ & 5 & 8 \\
\hline & of beam and slab & $12 / 2 / 2003$ & 8 & 8 \\
\hline & reinforcement & $13 / 2 / 03$ & 8 & 8 \\
\hline & & $14 / 2 / 03$ & 8 & 8 \\
\hline & & $18 / 2 / 03$ & 8 & 8 \\
\hline & & $19 / 2 / 03$ & 8 & 8 \\
\hline 7 & Casting of beam and slab & $22 / 2 / 03$ & 6 & 8 \\
\hline 8 & Dismantling of slab & $2 / 3 / 2003$ & 3 & 8 \\
\hline & $\begin{array}{l}\text { and beam scaffolding } \\
\text { and formwork }\end{array}$ & $3 / 3 / 2003$ & 4 & 8 \\
\hline $\begin{array}{l}\text { Remarks: } \\
\text { Labor Productivity }=\underline{\text { Cre }} \\
\quad \text { Gross Floor Area }\left(\mathrm{m}^{2}\right.\end{array}$ & $\frac{w \text { Size } \mathrm{x} \text { Work Time }}{71 \mathrm{~m}^{2} \times 6 \text { units }}=125$ & $=2.35 \mathrm{man}$ & & \\
\hline
\end{tabular}




\section{RESULTS AND DISCUSSION}

The data analysis and results focus on three specific subjects as described below:

* Labour productivity comparison between structural building systems using analysis of variance (ANOVA).

* Crew size comparison between structural building systems using analysis of variance (ANOVA), Pearson correlation test and simple linear regression.

* Cycle time comparison between structural building systems using analysis of variance (ANOVA), Pearson correlation test and simple linear regression.

Labor Productivity Comparison Between Structural Building Systems: This section evaluates the labor productivity comparison between structural building systems. Table 5 presents the descriptive statistic for labor productivity comparison between projects while Table 6 presents the labor productivity comparison between building systems using the average data from the seven projects. Analysis of Variance (ANOVA) results of labor productivity between the four building systems was found to be statistically significant different [ANOVA output, $\mathrm{F}(3,498)=319.526, P$ value $=0.000]$ as shown in Table 7 . The pre-cast concrete system was the most productive building system with labor productivity of $1.33 \mathrm{man}$ hours $/ \mathrm{m}^{2}$ followed by cast in-situ half tunnel (1.88 man hours $\left./ \mathrm{m}^{2}\right)$, cast in-situ table form $\left(2.70 \mathrm{man}\right.$ hours $\left./ \mathrm{m}^{2}\right)$ and conventional building system $\left(4.20 \mathrm{man}\right.$ hours $\left./ \mathrm{m}^{2}\right)$. Taking the conventional building system as the benchmark of $100 \%$, the cast in-situ table form system achieved a construction speed of $135 \%$ followed by the cast in-situ half tunnel form system of $155 \%$ and precast concrete system of $168 \%$.

The result was in tandem with the number of trades for each building system. For instance, the conventional building system was highly labor intensive because it consisted of four major operations, namely the erection of scaffolding and formwork, installation of reverse, casting of concrete and dismantling of scaffolding and formwork. On the other hand, the IBS required fewer construction operations. For instance, the cast in-situ tunnel form system did not require scaffolding to support the slab while the pre-cast concrete system was pre-assembly in the factory, hence reducing on-site labor input.

Crew Size Comparison between Structural Building Systems: Labor usage represents a critical factor in the Malaysian construction industry due to severe shortage of local workers. The industry relies heavily on foreign workers from Indonesia, Bangladesh, Thailand and Vietnam which precipitate economic and social problems. Hence, the identification of building a system that requires fewer workers is paramount. Theoretically, larger crew size shall induce better productivity due to large man-hour input. However, the large crew size can cause congestion and affect workers' movement. This in turn, affecting the workers' motivation and productivity. This section attempts to identify the optimal crew size for better labor productivity. Table 8 shows the crew size required for the completion of structural element of one house for each project while Table 9 shows the average crew size of the four structural building systems. Analysis of variance (ANOVA) results indicated that the mean crew size were not equal as shown in Table 10, [ANOVA output, $\mathrm{F}(3,498)=7.767, P$-value $=0.000]$. Further, Scheffe's method of multiple comparison was carried out to determine which means are not equal. The result indicated that the conventional building system was significantly different from the IBS. However, no significant difference was found between building systems in IBS. Hence, they were grouped into homogeneous subset as depicted in Table 11. On average, IBS required a crew size of 22 people while the conventional building system required a crew size of 24 people. These crew sizes were further broken down into carpenter, pre-cast panel erector, steel form erector, bartender, concrete and crane operator as shown in Table 12. In terms of percentage, the conventional building system required $7.0 \%$ more crew size than the IBS. This was because the conventional building system required more construction trades than the IBS.

It could be observed that the demand for carpenter was high for conventional building system with 8 workers followed by cast in-situ table form system of 6 workers and pre-cast concrete system of 2 workers (formwork for the gap between pre-cast concrete wall panel). However, the cast in-situ half tunnel form did not require the service of a carpenter but required 8 workers for erecting and installing steel tunnel form. Similarly, the cast in-situ table form system required 5 workers for erection and installation of steel wall form. On the other hand, the pre-cast concrete system needed 9 workers for erecting and fixing pre-cast concrete half slab and wall panels.

For steel reinforcement, the conventional building system employed the larger group of barbender with 9 workers followed by cast in-situ half tunnel form system of 7 workers and cast in-situ table form system and precast concrete system of 5 workers respectively. For concreting work, conventional building system, cast in-situ table form system and cast in-situ half tunnel form system required 6 workers respectively while the pre-cast concrete system required 5 workers only. Additionally, one crane operator was employed for all structural building systems. 
Table 5: Labor Productivity Comparison between Projects

\begin{tabular}{|c|c|c|c|c|c|c|}
\hline $\begin{array}{l}\text { Project } \\
\text { Code }\end{array}$ & $\begin{array}{l}\text { Structural } \\
\text { System }\end{array}$ & Building & $\begin{array}{l}\text { No. of } \\
\text { data point }\end{array}$ & $\begin{array}{l}\text { Mean Labor } \\
\text { productivity } \\
\text { (Manhours } / \mathrm{m}^{2} \text { ) }\end{array}$ & $\begin{array}{l}\text { Minimum labor } \\
\text { productivity } \\
\left(\text { Manhours } / \mathrm{m}^{2} \text { ) }\right.\end{array}$ & $\begin{array}{l}\text { Maximum labor } \\
\text { productivity } \\
\left(\text { Manhours } / \mathrm{m}^{2} \text { ) }\right.\end{array}$ \\
\hline A & Conventional & 100 & 3.91 & 2.35 & 6.81 & \\
\hline B & Conventional & 66 & 4.61 & 2.64 & 6.51 & \\
\hline $\mathrm{C}$ & IBS & $\begin{array}{l}\text { Cast in-situ } \\
\text { table form }\end{array}$ & 113 & 2.41 & 1.53 & 3.33 \\
\hline D & & $\begin{array}{l}\text { Cast in-situ } \\
\text { table form }\end{array}$ & 91 & 3.04 & 2.11 & 4.21 \\
\hline E & & $\begin{array}{l}\text { Cast in-situ half } \\
\text { tunnel form }\end{array}$ & 45 & 1.91 & 1.47 & 2.34 \\
\hline F & & $\begin{array}{l}\text { Cast in-situ half } \\
\text { tunnel form }\end{array}$ & 36 & 1.84 & 1.2 & 2.68 \\
\hline $\mathrm{G}$ & & Pre-cast concrete & 48 & 1.33 & 0.97 & 1.71 \\
\hline
\end{tabular}

Table 6: Labor Productivity Comparison between Structural Building Systems

\begin{tabular}{lllll}
\hline $\begin{array}{l}\text { Structural Building } \\
\text { System }\end{array}$ & $\begin{array}{l}\text { No. of } \\
\text { data point }\end{array}$ & $\begin{array}{l}\text { Mean Labor } \\
\text { productivity } \\
\left(\text { Man hours } / \mathrm{m}^{2}\right)\end{array}$ & $\begin{array}{l}\text { Minimum labor } \\
\text { productivity } \\
\left(\text { Man hours } / \mathrm{m}^{2}\right)\end{array}$ & $\begin{array}{l}\text { Maximum labor } \\
\text { productivity } \\
\left.\text { (Man hours } / \mathrm{m}^{2}\right)\end{array}$ \\
\hline Conventional & 166 & 4.2 & 2.35 & 6.81 \\
IBS Cast in-situ table form & 204 & 2.7 & 1.53 & 4.21 \\
Cast in-situ half tunnel form & 81 & 1.88 & 1.2 & 2.68 \\
Pre-cast concrete & 48 & 1.33 & 0.97 & 1.71 \\
\hline
\end{tabular}

Table 7: ANOVA Output for Labor Productivity Comparison between Structural Building Systems

\begin{tabular}{llllll}
\hline Source & Sum square & DF & Mean squares & F-Ratio & Significant level \\
\hline Between group & 484.692 & 3 & 161.564 & 319.526 & 0.000 \\
Within group & 250.290 & 495 & 0.506 & & \\
Total & 734.983 & 498 & & & \\
\hline
\end{tabular}

Table 8: Crew Size Comparison between Projects

\begin{tabular}{llllll}
\hline Project Code & Structural Building & No. of & Mean & Minimum & Maximum \\
& System & Data Point & Crew Size & Crew Size & Crew Size \\
\hline A & Conventional & 100 & 24 & 16 & 34 \\
B & Conventional & 66 & 23 & 17 & 30 \\
C & IBS Cast $i n$-situ table form & 113 & 21 & 12 & 27 \\
D & Cast $i n$-situ table form & 91 & 25 & 18 & 33 \\
E & Cast $i n$-situ half tunnel form & 45 & 21 & 16 & 28 \\
F & Cast $i$ - situ half tunnel form & 36 & 23 & 20 & 29 \\
G & Full pre-cast concrete & 48 & 22 & 16 & 27 \\
\hline
\end{tabular}

Table 9: Crew Size Comparison between Structural Building Systems

\begin{tabular}{|c|c|c|c|c|c|}
\hline \multicolumn{2}{|c|}{ Structural Building System } & Data point & Mean Crew Size & Minimum Crew Size & Maximum Crew Size \\
\hline \multicolumn{2}{|c|}{ Conventional } & 166 & 24 & 16.00 & 34.00 \\
\hline \multirow[t]{3}{*}{ IBS } & Cast in-situ table form & 204 & 23 & 12.00 & 33.00 \\
\hline & Cast in-situ half tunnel form & 81 & 22 & 16.00 & 29.00 \\
\hline & Pre-cast concrete & 48 & 22 & 16.00 & 27.00 \\
\hline
\end{tabular}

Table 10: ANOVA Output for Crew Size Comparison between Structural Building Systems

\begin{tabular}{llllll}
\hline Source & Sum square & DF & Mean squares & F-Ratio & Significant level \\
\hline Between group & 306.944 & 3 & 102.315 & 7.767 & 0.000 \\
Within group & 6520.543 & 495 & 13.173 & & \\
Total & 6827.487 & 498 & & & \\
\hline
\end{tabular}


Table 11: Scheffe's Method of Multiple Comparison between Structural Building Systems for Crew Size

\begin{tabular}{llll}
\hline Structural Building system & Data point & Crew Size & \\
& & Subset 1 & Subset 2 \\
\hline Conventional & & 166 & 24 \\
IBS & Cast in-situ table form & 204 & 23 \\
& Cast in-situ half tunnel form & 81 & 22 \\
& Precast concrete & 48 & 22 \\
\hline
\end{tabular}

Table 12: Crew Size Distribution According to Trades

\begin{tabular}{llllllll}
\hline $\begin{array}{l}\text { Structural } \\
\text { Building System }\end{array}$ & Carpenter & $\begin{array}{l}\text { Steel } \\
\text { Formwork } \\
\text { Erector }\end{array}$ & $\begin{array}{l}\text { Pre-cast } \\
\text { Panel } \\
\text { Erector }\end{array}$ & Barbender & Concretor & $\begin{array}{l}\text { Crane } \\
\text { operator }\end{array}$ & Total \\
\hline Conventional & 8 & Nil & Nil & 9 & 6 & 1 & 24 \\
IBS Cast in-situ table form & 6 & 5 & Nil & 5 & 6 & 1 & 23 \\
Cast in-situ half tunnel form & Nil & 8 & Nil & 7 & 6 & 1 & 22 \\
Pre-cast concrete & 2 & Nil & 9 & 5 & 5 & 1 & 22 \\
\hline
\end{tabular}

Table 13: Pearson Correlation between Labor Productivity and Crew Size

\begin{tabular}{lll}
\hline Structural Building System & No. of data point & Correlation coefficient (r) \\
\hline Conventional & 166 & 0.629 \\
IBS Cast $i$ - situ table form & 204 & 0.763 \\
$\quad$ Cast $i n$-situ half tunnel form & 81 & 0.382 \\
$\quad$ Pre-cast concrete & 48 & 0.525 \\
All building systems & 499 & 0.515 \\
\hline
\end{tabular}

Table 14: Mean Cycle Time (Days) Comparison between Projects

\begin{tabular}{llllll}
\hline Project Code & $\begin{array}{l}\text { Structural } \\
\text { Building System }\end{array}$ & $\begin{array}{l}\text { No. of } \\
\text { Data Point }\end{array}$ & $\begin{array}{l}\text { Mean Cycle } \\
\text { Time (days) }\end{array}$ & $\begin{array}{l}\text { Minimum Cycle } \\
\text { Time (days) }\end{array}$ & $\begin{array}{l}\text { Maximum Cycle } \\
\text { Time (days) }\end{array}$ \\
\hline A & Conventional & 100 & 4.1 & 2.8 & 7 \\
B & Conventional & 66 & 6.3 & 4 & 8 \\
C & IBS Cast in-situ table form & 113 & 3.9 & 3.5 & 5 \\
D & Cast in-situ table form & 91 & 4 & 3.5 & 5 \\
E & Cast in -situ half tunnel form & 45 & 2.8 & 2.5 & 4 \\
F & Cast in -situ half tunnel form & 36 & 3 & 1.5 & 5 \\
G & Pre-cast concrete & 48 & 2.3 & 2 & 3.5 \\
\hline
\end{tabular}

A Pearson's correlation was carried out to determine the extent of correlation between labor productivity and crew size. The correlation coefficient can range from a perfect positive correlation +1.0 to a perfect negative correlation -1.0. If two variables have no linear relationship, the correlation between them is 0 . The Pearson's correlation indicated that a positive linear relationship between crew size and labor productivity with a correlation coefficient (r) of 0.629 for conventional building system, $\mathrm{r}$ of 0.763 for cast in-situ table form system, $\mathrm{r}$ of 0.382 for cast in-situ tunnel form system, $\mathrm{r}$ of 0.525 for pre-cast concrete system and $\mathrm{r}$ about 0.515 for all combined building systems as shown in Table 13. All the correlations were significant at the 0.01 level. In other word, larger crew size decrease labor productivity due to overcrowding.

Further, a linear regression analysis ${ }^{[16]}$ is carried out which utilize the presence of an association between two variables to predict the dependent variable (labor productivity) from those of independent variables (crew size). The percentage of the total variation in the dependent variable that is explained by the independent variable is called the coefficient of determination $\left(R^{2}\right)$. $\mathrm{R}^{2}$ can be a value between 0 and 1.0. If there is a perfect linear relationship between two variables, the $\mathrm{R}^{2}$ will be 1.0. This would correspond to a situation in which the least squares regression line would pass through each of the points in the scatter plot. $\mathrm{R}^{2}$ is the measure used by many decision makers to indicate how well the linear regression line fits the $(\mathrm{X}, \mathrm{Y})$ data points. The better the fit, the closer $\mathrm{R}^{2}$ will be in 1.0. $\mathrm{R}^{2}$ will be close to 0 when there is a weak linear relationship or no relationship at all. The concept of using a linear correlation and regression analysis relates to the commonly held assumption that the best representation of prefect correlation is a straight (linear) regression line fitted to the observed data. A simple linear regression is represented by a linear equation of the general forms as shown in Eq. 1:

$P_{i}=\alpha+\beta_{1} X_{1}+e_{i} \ldots \ldots \ldots$

Eq. 1 
Table 15: Mean Cycle Time (Days) Per House Comparison between Structural Building Systems

\begin{tabular}{lllll}
\hline $\begin{array}{l}\text { Structural } \\
\text { Building System }\end{array}$ & Data point & $\begin{array}{l}\text { Mean Cycle } \\
\text { Time (days) }\end{array}$ & $\begin{array}{l}\text { Minimum Cycle } \\
\text { Time (days) }\end{array}$ & $\begin{array}{l}\text { Maximum Cycle } \\
\text { Time (days) }\end{array}$ \\
\hline Conventional & 166 & 4.9 & 2.8 & 8 \\
IBS Cast in-situ table form & 204 & 3.9 & 3.5 & 5.5 \\
Cast in-situ half tunnel form & 81 & 2.9 & 1.5 & 5 \\
Pre-cast concrete & 48 & 2.3 & 2 & 3.5 \\
\hline
\end{tabular}

Table 16: ANOVA Output For Cycle Time Comparison between Structural Building Systems

\begin{tabular}{llllll}
\hline Source & Sum square & DF & Mean squares & F-Ratio & Significant level \\
\hline Between group & 375.963 & 3 & 125.321 & 161.416 & 0.000 \\
Within group & 384.311 & 495 & 0.776 & & \\
Total & 760.273 & 498 & & & \\
\hline
\end{tabular}

Table 17: Pearson Correlation between Labour Productivity and Cycle Time

\begin{tabular}{|c|c|c|c|}
\hline Struc & Building System & No. of data point & Correlation coefficient (r) \\
\hline Con & onal & 166 & 0.619 \\
\hline IBS & Cast in-situ table form & 204 & 0.232 \\
\hline & Cast in-situ half tunnel form & 81 & 0.363 \\
\hline & Pre-cast concrete & 48 & 0.266 \\
\hline & All building system & 499 & 0.781 \\
\hline
\end{tabular}

Where:

$\mathrm{P}_{\mathrm{i}}=$ Labor productivity for the structural element of one house (man hours $/ \mathrm{m}^{2}$ )

$\beta_{\mathrm{I}}=$ The slope of the regression line that measures the average change in the labor productivity for each unit change in independent variable $\mathrm{Xi}$

$\alpha=$ indicate the mean value of labor productivity when all $X_{i}=0$. This value is valid only when the labor productivity can have $X_{i}$ value of 0 . This will not occur since independent variable such as crew size can not be zero.

$\mathrm{X}_{\mathrm{i}}=$ Independent variables (crew size)

The simple linear regression analysis indicated that there were significant relationship between labor productivity and crew size for all building systems under study with an R2 of 0.404 for conventional building system, $\mathrm{R}^{2}$ of 0.588 for cast in-situ table form system, $\mathrm{R}^{2}$ of 0.163 for cast in-situ tunnel form system and $\mathrm{R}^{2}$ of 0.281 for pre-cast concrete system and $\mathrm{R}^{2}$ of 0.282 for all building systems in total. Hence, the crew size variable can be used as the independent variable in labor productivity forecasting model using multiple regression analysis. The best regression line between labor productivity and crew size for the conventional, cast in-situ form, cast in-situ tunnel form, pre-cast concrete and all building systems are presented in Equation 2-6.

$$
\begin{aligned}
& \mathrm{P}_{\text {conventional }}=1.983+0.003755(\mathrm{X})^{2}{ }_{\text {crew size }}\left(\mathrm{R}^{2}=0.404\right) \\
& \mathrm{P}_{\text {cast in-situ table form }}=1.545+0.002132(\mathrm{X})^{2}{ }_{\text {crew size }}\left(\mathrm{R}^{2}=0.588\right) \\
& \mathrm{P}_{\text {cast in-situ tunnel form }}=1.517+0.00003272(\mathrm{X})^{3} \text { crew size }\left(\mathrm{R}^{2}=0.163\right) \\
& \mathrm{P}_{\text {pre-cast concrete }}=1.11+0.00002053(\mathrm{X})^{3} \text { crew size } \\
& \left(\mathrm{R}^{2}=0.281\right)
\end{aligned}
$$

Eq. 5
$\mathrm{P}_{\text {all building systems }}=1.601+0.0001014(\mathrm{X})^{3}$ crew size $\left(\mathrm{R}^{2}=0.282\right) \quad$ Eq. 6

Cycle Time Comparison between Structural Building Systems: This section examines the cycle time measured in days required to complete the structural element of one unit house. Table 14 shows the cycle time for each project while Table 15 shows the average cycle time for four structural building systems.

Analysis of variance (ANOVA) results indicated that there was a significant difference between the four building systems in term of cycle time per house as shown in Table 16, $[\mathrm{F}(3,498)=161.416, P$-value $=$ 0.000]. The mean cycle times were 4.9 days for conventional building system, 3.9 days for cast in-situ table form, 2.9 days for cast in-situ half tunnel form and 2.3 days for the pre-cast concrete system. In terms of percentage, the conventional building system required $26 \%$ more cycle time than cast in-situ table form system, $41 \%$ of cast in-situ half tunnel form system, $53 \%$ of pre-cast concrete system.

By knowing the mean cycle time for completion of structural element of one house, the total construction duration for a project can be pre-determined. This can also be used to evaluate the project extension of time (EOT) submitted by the contractor.

A Pearson correlation was carried out to determine the extent of correlation between labor productivity and cycle time. The Pearson correlation indicated that a positive linear relationship between cycle time and labor productivity with a correlation coefficient $(r)$ of 0.619 for conventional building system, $\mathrm{r}$ of 0.232 for cast in-situ table form system, $\mathrm{r}$ of 0.363 for cast in-situ tunnel form system, $\mathrm{r}$ of 0.266 for pre-cast concrete system and $r$ about 0.781 for all building systems in 1022 
total as shown in Table 17. All the correlations were significant at the 0.01 level. This implied than the longer construction period decreased labor productivity because more man hours input where required.

The linear regression analysis was carried to study the extent of the relationship between labor productivity and cycle time. It can be observed that there were a significant relationship between labor productivity and cycle time for all building systems under study with an $\mathrm{R} 2$ of 0.500 for conventional building system, $\mathrm{R}^{2}$ of 0.110 for cast in-situ table form system, $\mathrm{R}^{2}$ of 0.318 for cast in-situ tunnel form system and $\mathrm{R}^{2}$ of 0.071 for precast concrete system and $\mathrm{R}^{2}$ of 0.628 for all building systems in total. Hence, the cycle time variable can be used as the independent variable in labor productivity forecasting model using multiple regression analysis. The best regression line between labor productivity and cycle time for the conventional, cast in-situ form, cast in-situ tunnel form, pre-cast concrete and all building systems are presented in Equation 7-11.

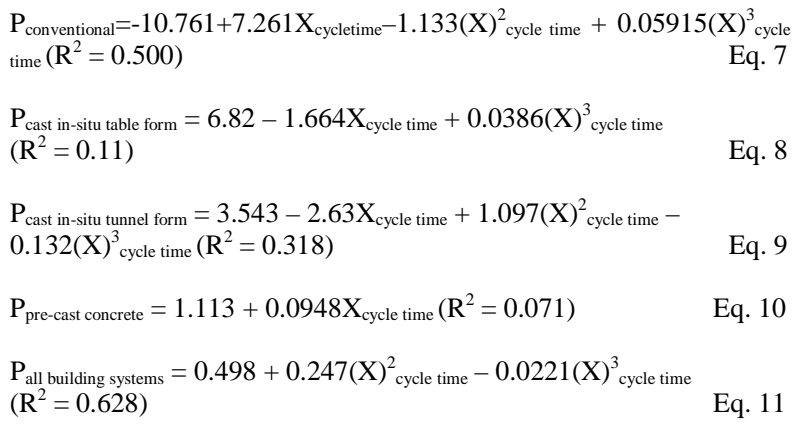

\section{CONCLUSION}

This study has presented the standardized data collection methodology for measuring and comparing the building structural element of conventional and industrialized building system. This methodology allows researchers to combine data points from various projects to create a larger database. The rationale for combining the data point is that the majority of residential projects have a simple structural layout plan and do not have any peculiarities architectural features. A total of 499 labor productivity data points was acquired from seven on-going residential projects. The results and discussion evolves on comparison between structural building systems in terms labor productivity, crew size and cycle time per structural element of one house.

The labor productivity comparison indicated that the pre-cast concrete system was the most productive building system with labor productivity of 1.33 manhours $/ \mathrm{m}^{2}$ followed by cast in-situ half tunnel system (1.88 man hours $\left./ \mathrm{m}^{2}\right)$, cast in-situ table form system $\left(2.70\right.$ man hours $/ \mathrm{m}^{2}$ ) and conventional building system (4.20 man hours $/ \mathrm{m}^{2}$ ). Taking the conventional building system as the benchmark of $100 \%$, the cast insitu table form system achieved a construction speed of $135 \%$ followed by the cast in-situ half tunnel form system of $155 \%$ and pre-cast concrete system of $168 \%$.
For crew size comparison, results indicated the conventional building system was a significant difference from the IBS. However, no significant difference was observed for building systems within the IBS. The mean crew size required to complete the structural element of one house for the conventional building system was 24 workers while the IBS was 22 workers. These workers were further divided into carpenter, bartender, concrete, steel form erector, precast concrete panel erector and crane operator. In terms of percentage, the conventional building system required $7.0 \%$ more crew size than the IBS.

In terms of cycle time per house comparison, the four building systems were significantly different. The mean cycle times were 4.9 days for conventional building system, 3.9 days for cast in-situ table form, 2.9 days for cast in-situ half tunnel form and 2.3 days for the pre-cast concrete system. In terms of percentage, the conventional building system required $26 \%$ more cycle time than cast in-situ table form system, $41 \%$ of cast insitu half tunnel form system, 53\% of pre-cast concrete system.

The analysis of correlation between labor productivity and crew size using Pearson's correlation indicated that a significant positive correlation (correlation coefficient of 0.515) between them. Similarly, the cycle time was also found to have strong significant positive correlation (correlation coefficient of 0.781) with labor productivity. The labor productivity acquired from this study could be used for predicting labor input, labor cost, labor accounting, cost control and construction duration.

\section{ACKNOWLEDGEMENT}

The authors would like to acknowledge the help provided by the Construction Industry Development Board, Malaysia (CIDB) and Intensification of Research in Priority Areas, (IRPA) of $7^{\text {th }}$ Malaysia Plan for funding this study.

\section{REFERENCES}

1. Koehn, E. and G. Brown, 1986. International labor productivity factors. J. Construction Engineering and Management, 112: 229-302.

2. Anon., 1992. Raising Singapore's construction productivity. Singapore, CIDB Construction Productivity Taskforce Report.

3. Din, H., 1984. Industrialized building and its application in Malaysia. Seminar on Prefabrication of Building Construction, Kuala Lumpur, pp: 2024.

4. Badir, Y.F., M.R.A. Kadir and A.H. Hashim, 2002. Industrialized building systems construction in Malaysia. J. Architect. Eng., 8: 1-5.

5. Rollet, M., 1986. Modular coordination in the building industry- Toward industrialization in the building industry. Proceeding of a UNESCO/FEISEAP Regional Workshop at Universiti Pertanian Malaysia, Serdang. 
6. Trikha, D.N., 1999. Industrialized building systems. Prospects in Malaysia. Proceedings of World Engineering Congress, Kuala Lumpur.

7. Esau, H. and M.M. Nuruddin, 1998. Policy of industrialized building system. Report on Colloquium on Industrialized Construction System, Kuala Lumpur, April.

8. Warszawski, A., 1999. Industrialized and automated building systems. Technion-Israel Institute of Technology. E and FN Spon.

9. Junid, S.M.S., 1986. Industrialized building system. Proceedings of a UNESCO/FEISEAP Regional workshop, UPM Serdang.

10. Badir, Y.F., M.R.A. Kadir and A.A.A. Ali, 1998. Theory of classification on Badir-Razali Building system classification. Bulletin of Institution of Engineers, Malaysia, October.

11. Majzub, 1977. Modular housing systems used around the world. Intl. J. Housing Sci., 1: 5-10.
12. Anson, M. and S.Q. Wang, 1998. Performance of concrete placing in Hong Kong Buildings. J. Construction Eng. Manag., 124: 116-124.

13. Salim, M. and L.E. Bernold, 1994. Effects of design integrated process planning on producing in rebar placement. J. Construction Eng. Manag., 120: 720-738.

14. Proverbs, D.G, G.D. Holt and P.O. Olomolaiye, 1998. A comparative evaluation of planning engineers' formwork productivity rates in European construction. Built and Environment, 33: 181-187.

15. Thomas, H.R. and I. Yiakoumis, 1987. Factor model of construction productivity. J. Construction Eng. Manag., 113: 623-639.

16. Hair, J.F., R.E. Anderson, R.L. Tatham and W.C. Black, 1998. Multivariate Data Analysis. Upper Saddle River, New Jersey, $5^{\text {th }}$ Edn, Prentice Hall. 